\title{
EDITORIAL
}

\section{Importancia de las revistas de investigación propias para una universidad}

\author{
Importance of in-house research journals for a university
}

\author{
Víctor Gerding \\ Universidad Austral de Chile, Facultad de Ciencias Forestales y Recursos Naturales, \\ editor de Bosque, Valdivia, Chile, vgerding@uach.cl
}

Bosque, desde su fundación en 1975, ha seguido una trayectoria bastante clásica como revista de carácter universitario, transitando desde una selección de artículos mayoritariamente originados en Chile hasta su situación actual eminentemente internacional con minoría de artículos de autores nacionales. Así, Bosque publica aportes de la ciencia de muchos países de todos los continentes, aunque ha generado mayor atracción para investigadores de Latinoamérica, posiblemente porque publica artículos en español (y también en inglés) o porque la temática forestal de tal región sea más cercana y sensible para sus equipos editoriales. Para Bosque y una decena de otras revistas de investigación, la casa editora es la Universidad Austral de Chile, la cual posibilita que investigadores de otras latitudes tengan medios donde publicar su producción científica; es decir, esta Universidad actúa como una editorial de revistas científicas.

Muchas otras universidades también editan revistas científicas propias, haciéndose parte de las miles de revistas publicadas en el mundo donde dominan varias casas editoras especializadas de alto nivel. Sin embargo, las universidades son juzgadas en parte sustancial por su producción científica, representada en la cantidad y calidad de los artículos científicos que sus académicos publican periódicamente. Además, las mínimas normas éticas establecen que una revista científica de una universidad no esté destinada a ser el órgano de publicación de su propia investigación científica; es decir, salvo situaciones justificadas, las revistas de alto impacto no deben estar soportadas por la producción científica de la misma casa. En esto también contribuyen las políticas de financiamiento público a la investigación, que desincentivan o penalizan la publicación de artículos de un académico en una revista de su misma casa de estudios. Todo ello se traduce en que los académicos que cumplen funciones editoriales generalmente no sean evaluados por dicho quehacer y, muchas veces, su trabajo y responsabilidad sean francamente ignorados en los mecanismos de evaluación y promoción académica.

Entonces, si existen suficientes revistas no universitarias de alta calidad en el ámbito editorial científico, si los miembros de una universidad deben limitarse o abstenerse de publicar en sus propias revistas, y si los académicos y sus universidades no son evaluados por lo que editan sino por lo que producen como contenido científico, ¿por qué muchas universidades editan revistas científicas propias y por qué deberían seguir haciéndolo en este escenario de condiciones “adversas"? Existen razones para ello, unas más importantes que otras según cada universidad, además de otros factores, pero tienen relevancia para tales instituciones, porque las revistas de investigación propias de una universidad cooperan en funciones académicas consustanciales y en el desarrollo general del conocimiento científico (Ochoa 2014, Pire 2015, Repiso et al. 2019). Sobre las razones de tal importancia, para cualquier universidad se debe considerar que sus propias revistas:

- Promueven la identidad de sus miembros con la institución.

- Son un medio de vinculación de la universidad con el medio.

- Difunden conocimiento científico a todo el mundo, especialmente cuando adscriben a los principios de acceso abierto justo (FOAA 2020).

- Representan un reconocimiento de la calidad de los equipos académicos para editar conocimiento científico originado en cualquier parte del mundo.

- Demuestran confianza de los científicos de cualquier origen en los equipos académicos de la universidad para someter sus trabajos de investigación a la gestión editorial.

- Son una instancia de aprendizaje -especialmente en programas de posgrado- sobre importantes aspectos de la producción de conocimiento científico y, particularmente, de la evaluación y la difusión de sus contenidos.

- Ofrecen oportunidades para que autores noveles tengan sus primeras experiencias en la escritura científica, sobre la cual no se ofrece formación sistemática ni suficiente en la universidad, cuando tales revistas carecen indexación o presenta indexación menor. 
- Representan todas o una parte relevante de las áreas del conocimiento de la universidad.

- Aportan elementos fácilmente valorables, por ejemplo, mediante sus indexaciones y volúmenes de trabajos editados, por lo que su calificación puede lograrse sencillamente por parte de la administración universitaria.

- Pueden tener mayor acercamiento hacia problemas y comunidades locales, facilitando el desarrollo de líneas de investigación que no tienen cabida en contextos internacionales, pero que son relevantes para el país o región donde se encuentra la universidad, favoreciendo además el contacto entre una universidad y su entorno.

- Si además son consideradas como referentes internacionales, proyectan investigación de alta calidad del país, consolidan el prestigio en un área y pueden contribuir a aumentar la obtención de recursos económicos y humanos.

Adicionalmente, las revistas propias de una universidad coadyuvan en aspectos generales del desarrollo del conocimiento científico. Por ejemplo:

- Son parte del repositorio de conocimiento científico de acceso abierto.

- Custodian el conocimiento científico que publican.

- Contribuyen en uno de los principales elementos de evaluación de la academia, mediante transferencia del conocimiento científico, otorgando acceso a la publicación de resultados científicos.

- Constituyen parte de la estrategia de soberanía o independencia del conocimiento científico con respecto al mercado de la ciencia.

- En el caso de las universidades de servicio público, permiten la participación de una institución de carácter público en el circuito de la creación de conocimiento científico.

- Aportan al beneficio social o económico de la industria, de la sociedad o de la misma universidad.

De este conjunto de aportes y atributos se colige que las revistas científicas propias de una universidad son importantes para dicha institución académica y, por lo tanto, es comprensible que muchas universidades con altos estándares de investigación científica sean, a su vez, casas editoras de revistas científicas. Y como ello debiese continuar siendo así, resulta paradójico que en casi todas las universidades la función de editor de tales revistas no tenga el reconocimiento académico y estatutario que merece para alcanzar o mantener los mejores estándares de calidad editorial. Esto último dificulta reclutar suficientes académicos dispuestos a realizar una labor que no se detiene ni en días feriados ni en vacaciones. Como consecuencia, la gestión editorial de las revistas científicas de las universidades enfrenta permanentes amenazas de inestabilidad, discontinuidad o desaparición.

Por lo tanto, para salvaguardar las importantes funciones de las revistas científicas propias de la universidad y asegurar su continuidad con creciente mejoría en la calidad, es imprescindible que las universidades establezcan reconocimientos que incentiven la participación de académicos, tanto de destacada trayectoria como de incipiente carrera, para asumir las diversas y abundantes funciones editoriales de sus revistas.

\section{REFERENCIAS}

FOAA (Fair Open Access Alliance, NL). 2020. The Fair Open Access Principles. Consultado 10 ene. 2020. Disponible en https://www. fairopenaccess.org/the-fair-open-access-principles/

Ochoa FL. 2014. De la importancia de las revistas institucionales. CES Medicina 28(2):163-164. http://www.scielo.org.co/pdf/cesm/ v28n2/v28n2a01.pdf

Pire R. 2015. La importancia de las revistas científicas universitarias y la necesidad de su financiamiento. Compendium 18(35): 2-3. https://www.redalyc.org/pdf/880/88043199001.pdf

Repiso R, D Torres-Salinas, I Aguaded. 2019. La gestión de revistas: mérito de transferencia universal. Justo y necesario. Anuario ThinkEPI 13: e13e03. DOI: https://doi.org/10.3145/thinkepi.2019.e13e03 
Since its foundation in 1975, Bosque has followed a fairly classical path as a university outset journal, transiting from a selection of articles mostly originating in Chile to its eminently international present situation with a minority of articles by national authors. Thus, Bosque publishes scientific contributions from many countries on all continents, although it has proven more attractive to researchers of Latin America, possibly because it publishes articles in Spanish (although also in English) or because the forestry issues of that region are more meaningful and more sensitive for its editorial teams. For Bosque and a dozen other research journals, the publishing house is the Universidad Austral de Chile, which provides room for researchers from other latitudes to publish their scientific production; in other words, this University acts as a publisher of scientific journals.

Many other universities also publish their own scientific journals, thus becoming part of the thousands of journals published in the world where several highly specialized publishing houses prevail. However, universities are by and large judged by their scientific production evidenced in the number and quality of scientific articles that their academics publish periodically. In addition, the existing minimum ethical standards state that a university's scientific journal is not intended to be the publishing body of its own scientific research; that is, high impact journals should not be supported, except in justified situations, by the scientific production of the same house. Public funding policies for research that discourage or penalize the publication of an academic's articles in a journal of their own university also contribute to this. In this way, academics who carry out editorial functions are seldom evaluated for the work they do and, many times, their job and responsibility are frankly ignored when it comes to facing evaluation and academic promotion.

Therefore, if there are enough high-quality, non-university journals in the scientific publishing field, if university members must abstain themselves or refrain from publishing in their own journals, and if academics and their universities are not evaluated by what they edit but by the scientific content they produce, why do many universities edit their own scientific journals and why should they continue to do so in this scenario of "adverse" conditions? There are reasons for this, some more important than others according to each university, and there are other factors, but they are relevant for those institutions because a university's own research journals cooperate in consubstantial academic functions and in the general development of scientific knowledge (Ochoa 2014, Pire 2015, Repiso et al. 2019). Regarding the reasons for such importance, any university should consider that its own journals:

- Promote the identity of their members with the institution.

- Are a means of linking the university with society.

- Disseminate scientific knowledge around the world, especially when they adhere to the principles of fair open access (FOAA 2020).

- Represent a recognition of the quality of the academic teams to edit scientific knowledge originated in any part of the world.

- Prove the trust of scientists of any origin in the university's academic teams to submit their research works to the editorial management.

- Are an instance of learning -especially in postgraduate programs- about important aspects of the production of scientific knowledge and, particularly, of the evaluation and dissemination of contents.

- Offer opportunities for new authors to have their first experiences in the writing of scientific papers, about which no systematic or sufficient training is offered at the university, when journals lack indexation or have a lower-impact index.

- Represent all or an important part of the university's areas of knowledge.

- Provide elements that can easily be assessed, for example, through their indexing and volumes of published works; so, their evaluation can simply be achieved by the university management.

- Can have a closer approach to local problems and communities, facilitating the development of research lines that have no place in international settings, but that are relevant to the country or region where the university is located, which also favors contact between the university and its surroundings.

- If they are additionally considered as international references, they represent a country's high quality research prospects, consolidate their prestige in an area and can contribute to increase the possibility of obtaining economic and human resources.

Additionally, a university's journals contribute to the improvement of general aspects of the development of scientific knowledge. For example:

- They are part of the open access scientific knowledge repository.

- They safeguard the scientific knowledge they publish.

- They contribute to one of the main elements of evaluation of the academy, through the transfer of scientific knowledge, granting access to the publication of scientific results. 
- They constitute part of the strategy of sovereignty or independence of scientific knowledge from the science market.

- In the case of public universities, they allow the participation of a public institution in the circuit of scientific knowledge creation.

- They contribute to the social or economic benefit of industry, society or the university itself.

From this set of contributions and attributes, it is possible to assume that a university's scientific journals are important for that academic institution and, therefore, it is understandable that a large number of universities with high standards of scientific research are, at the same time, publishers of scientific journals. And since this should continue to be the case, it is paradoxical that in almost all universities the role of the editor of such journals does not have the academic and statutory recognition it deserves in order to achieve or maintain the highest editorial quality standards. The last-mentioned aspect makes it difficult to recruit enough academics who are willing to do a job that does not stop at holidays or on vacations. Consequently, the editorial management of scientific journals at universities is faced with permanent threats of instability, discontinuity or disappearance.

Therefore, in order to safeguard the important functions of the university's own scientific journals and ensure their continuity with increasing quality improvement, it is essential that universities establish recognition that encourages the participation of academics, both of outstanding and incipient careers, to assume the diverse and numerous editorial functions of their journals. 